\title{
PENGEMBANGAN PERANGKAT PEM BELAJARAN BERBASIS SCIENTIFIC APPROACH UNTUK MEMBANGUN KARAKTER KEPEDULIAN DAN KEDISIPLINAN
}

\author{
Veryliana Purnamasari dan M uhammad N ur Wangid \\ FIP Universitas N egeri Yogyakarta \\ email: verylianapurnamasari@gmail.com
}

\begin{abstract}
A bstrak: Penelitian ini bertujuan menghasilkan perangkat pembelajaran berbasis scientific approach Keindahan A lam N egeriku yang layak bagi kelas IV SD untuk membangun karakter kepedulian dan kedisiplinan dan mengetahui keefektifannya. Penelitian ini merupakan penelitiandan pengembangan yang mengacu pada model Borg \& Gall. Subjek uji coba siswa kelas IV SDN Salamrejo Sentolo, Kulon Progo. Subjek uji coba awal terdiri atas 4 siswa. Subjek uji coba lapangan terdiri atas 10 siswa yang belum terlibat dalam uji coba awal, dan subjek uji lapangan operasional terdiri atas 39 siswa dari kelas IVA dan kelas IVB. Hasil penelitian berupa perangkat pembelajaran yang meliputi: silabus, RPP, LKS, dan instrumen penilaian. Hasilnya menunjukkan perangkat pembelajaran yang telah dikembangkan layak menurut ahli materi dan ahli pembelajaran dengan kategori penilaian sangat baik. Perangkat pembelajaran dinilai efektif karena hasil uji t pada karakter peduli sebesar 4,854 dan karakter disiplin sebesar 1,926 lebih besar dari t table yaitu 1,684 sehingga menunjukkan ada perbedaan yang signifikan terhadap karakter disiplin dan peduli antara siswa yang mengikuti pembelajaran tanpa perangkat pembelajaran dan yang menggunakan perangkat pembelajaran hasil pengembangan.
\end{abstract}

Kata Kunci: pengembangan, perangkat pembelajaran, scientific approach, karakter

\begin{abstract}
This study aims to (1)produce a learning device based on scientific approach that can be feasible to develop the character of elementary school fourth graders especially caring and discipline character and (2) determine the effectiveness of learning device based on scientific approach that can develop the character of elementary school fourth graders especially caring and discipline character. This was a research and development $(R \& D)$ study consisting of ten stages, namely: (1) preliminary study and data collection, (2) planning, (3) product draft development, (4) preliminary field tryout, (5) revision of the tryout result, (6) field tryout, (7) product finalization based on the field tryout result, (8) operational field testing, (9) final product finalization and (10) dissemination and implementation. The tryout subjects were Grade IV students of SD N Salamrejo Sentolo Kulon Progo. The preliminary field tryout subjects consisted of four students. The main field testing subjects consisted of ten students who were not involved in the preliminary field tryout. The operational field tryout subjects consisted of 39 students from Grade IV A and Grade IV B.The result of this research is a learning device consisting of a syllabus, lesson plans, student worksheets, and assessment instruments. The resultsof expert show that the learning device has been developed is feasible according to the material expertand learning expert with excellent assessment category. The device is also consid ered an effective learning because the results of the t test on the character of caring are 4.854, in the character of the discipline 1.926 which greater than $t$ table is 1.684 indicating significant difference of the character of discipline and care among the students who follow the teaching and learning and those without using learning device.
\end{abstract}

Keyw ords: development, learning device, scientific approach, characters.

\section{PEN DAHULUAN}

Pemerintah Indonesia terus meningkatkan kualitas untuk mengembangkan sumber daya manusia yang ada, salah satunya melalui pendidikan. Hal yang dilakukan sejalan dengan Undang-Undang No- 
mor 20 Tahun 2003 tentang Sistem Pendidikan Nasional (UU Sisdiknas) yang menjelaskan bahwa pendidikan nasional berfungsi mengembangkan kemampuan dan membentuk watak serta peradaban bangsa yang beradab dalam rangka mencerdaskan kehidupan bangsa, bertujuan untuk berkembangnya potensi peserta didik agar menjadi manusia yang beriman dan bertakwa kepada Tuhan Yang Maha Esa, berakhlak mulia, sehat, berilmu, cakap, kreatif, serta menjadi warga negara yang demokratis dan bertanggung jawab (Pasal 3).

Sesuai dengan undang-undang di atas, pemerintah telah mengembangkan Kurikulum 2013 yang diharapkan dapat membekali anak-anak Indonesia menuju persaingan yang semakin ketat. Tujuan Kurikulum 2013 yaitu mempersiapkan manusia Indonesia agar memiliki kemampuan hidup sebagai pribadi dan warga negara yang beriman, produktif, kreatif, inovatif, dan afektif serta mampu berkontribusi dalam kehidupan bermasyarakat, berbangsa, bernegara, dan peradaban dunia (Permendikbud No. 67 Tahun 2013).

Pengembangan kurikulum tidak hanya dari segi pengetahuan saja, namun juga ditekankan adanya karakter peserta didik. Upaya untuk mewujudkan karakter tersebut, dilakukan mulai dari pendidikan dasar yaitu jenjang pendidikan yang ditempuh selama 6 tahun sejak anak berusia 6 atau 7 tahun. Pendidikan Dasar yang dimaksud oleh UU Sisdiknas Bab VI, Pasal 17 ayat pertama bahwa pendidikan dasar merupakan jenjang pendidikan yang melandasi jenjang pendidikan menengah. Pada ayat kedua ditegaskan, pendidikan dasar berbentuk Sekolah Dasar (SD) dan Madrasah Ibtidaiyah (MI) atau bentuk lain yang sederajat serta Sekolah Menengah Pertama (SMP) dan Madrasah Tsanawiyah (MTs), atau bentuk lain yang sederajat.
Setiap jenjang pendidikan mempunyai struktur kurikulum tertentu mulai dari tingkat yang paling sederhana di sekolah dasar hingga yang sangat kompleks di perguruan tinggi. Demikian pula dalam pelaksanaan Kurikulum 2013 yang menekankan pada penggunaan scientific approach dan authentic assessment. Tessier (2003:25) menuliskan, "The scientific method provides an excellent framew orkfor actively involving students in their own learning and scientific research has been promoted as a teaching model." Scientific approach menyediakan kerangka kerja yang sangat baik untuk secara aktif melibatkan siswa dalam pembelajaran mereka sendiri. Scientific approach memfasilitasi siswauntuk aktif mencari pengetahuan baru secara mandiri melalui proses melakukan pengamatan, bertanya, melakukan percobaan, mengolah data atau informasi, menyajikan data atau informasi, dilanjutkan dengan menganalisis, menalar, kemudian menyimpulkan, dan terahir mencipta.

A uthentic assessment merupakan peniIaian yang tidak hanya mengukur hasil, akan tetapi lebih menekankan untuk mengukur proses yang dilakukan siswa. $\mathrm{Hal}$ ini didukung oleh pendapat Usman (2011:159) bahwa authentic assessment adalah suatu asesmen hasil belajar yang menuntut peserta didik dapat menunjukkan hasil belajar berupa kemampuan dalam kehidupan nyata, bukan sesuatu yang dibuat-buat atau hanya diperoleh pada proses pembelajaran di kelas, tetapi juga yang terjadi pada kehidupan sehari-hari.

Melalui Kurikulum 2013 diharapkan dapat terbentuk karakter yang kuat pada peserta didik. Karakter merupakan ciri khas seseorang yang membedakan kualitas antarindividu. Karakter tidak hanya apa yang terlihat di permukaan, melainkan lebih ke dalam, yakni kepribadian individu tersebut. Pernyatan ini didukung oleh 
Bohlin (2005: 159) yang menyatakan, “Character is that distinctive mark of our person; the combination of these distinguishing qualities that make us who we are. Character is deeper than appearance and reputation and constitutes more than our personality or temperament". Namun, kenyataannya karakter peserta didik saat ini masih kurang, terutama dalam hal kepedulian dan kedisiplinan. $\mathrm{Hal}$ ini terlihat dari kurangnya kepedulian peserta didik, khususnya kepedulian terhadap lingkungan. Ketidakpedulian terhadap lingkungan tersebut tercermin dari sikap peserta didik yang masih suka membuang sampah sembarangan, mencoretcoret tembok atau meja, dan tidak mau membersihkan lingkungan sekitar sekolah. Kepedulian seharusnya dikembangkan sedini mungkin karena kepedulian tidak dapat tumbuh dengan sendirinya. Hal ini didukung oleh pernyataan Lickona (1991:312), "To cultivate caring, as with any other moral quality, requires a learning-by-doing approach that develops all three aspect of character: knowing, feeling, and action." Kepedulian membutuhkan proses untuk dapat tumbuh da lam kehidupan seseorang. Proses tersebut antaralain proses pengetahuan, perasaan dan tindakan.

Kedisiplinan peserta didik juga masih terbilang kurang. $\mathrm{H}$ al tersebut terlihat dari sikap perserta didik yang datang terlambat, enggan menaati tata tertib. Misalnya, tidak mau menjalankan piket kelas maupun kerja bakti. Setiap kali piket kelas, guru sering kali menegur dan bahkan memarahi hingga peserta didik tersebut mau menjalankan piket kelas. Begitu pula saat kerja bakti di sekolah. Beberapa siswa terlihat enggan melakukannya. Seharusnya disiplin menjadi dasar penting dalam membangun karakter. Seperti yang dijelaskan oleh Dwiningrum, dkk (2013:83) bahwa disiplin merupakan salah satu tujuan sosiali- sasi. Kegagalan dalam mencapai tujuan sosialisasi pada diri individu akan berpengaruh dalam kehidupan keluarga maupun masyarakat.

Pengembangan karakter kepedulian dan kedisiplinan dimulai dengan pembiasaan di sekolah yang dilakukan terintegrasi dengan pembelajaran di sekolah. Oleh karena itu, dibutuhkan suatu perangkat pembelajaran yang dapat mengakomodasi penerapan karakter tersebut.

Perangkat pembelajaran akan sangat membantu guru dalam menyampaikan proses mencari pengetahuan kepada peserta didik. Borich (2007:112) menyatakan "Planning is the systematic process of deciding what and how your students should learn." Perencanaan adalah proses yang sistematis untuk memutuskan apa dan bagaimana siswa harus belajar. Akan tetapi, kenyataan di lapangan menunjukkan bahwa SDN Salamrejo mengalami permasalahan terkait dengan pengembangan perangkat pembelajaran tersebut. Salah satu permasalahan yangmuncul adalah belum dikembangkannya perangkat pembelajaran yang mengakomodasi pengembangan karakter.

Berdasarkan hasil wawancara yang dilakukan dengan seorang guru di SDN Salamrejo pada tanggal 7 Juli 2013, guru belum mengembangkan perangkat pembelajaran kelas IV SD berbasis scientific approach yang dapat digunakan untuk membangun karakter kepedulian dan kedisiplinan, seperti silabus, RPP dan panduan penilaian. Panduan mengajar saat ini hanya berupa buku guru dan buku siswa dari pemerintah.

Berdasarkan pemaparan di atas, hal yang sangat dibutuhkan dalam rangka pengimplementasian Kurikulum 2013 dan pengembangan karakter adalah perangkat pembelajaran yang menjadi acuan guru untuk mengajar. Oleh karena itu, perlu di- 
kembangkannya perangkat pembelajaran berbasis scientific approach dalam rangka membangun karakter kepedulian dan ke disipilinan. Perangkat pembelajaran ini diharapkan dapat mempermudah guru dalam melaksanakan proses belajar mengajar sehingga ketercapaian tujuan pembelajaran dalam Kurikulum 2013 lebih maksimal. Salah satu subtema yang tepat dalam pengembangan karakter kepedulian dan kedisiplinan ini adalah subtema "Keindahan Alam Negeriku". Perangkat pembelajaran untuk mengembangkan karakter kedisiplinan dan kepedulian pada subtema ini belum dikembangkan di SDN Salamrejo sehingga akan sangat bermanfaat dan dapat digunakan untuk memenuhi kebutuhan guru. Adapun perangkat pembelajaran yang dikembangkan dalam penelitian ini adalah silabus, RPP, LKS dan instrumen penilaian.

\section{METODE}

Jenis penelitian ini adalah penelitian dan pengembangan (Research and Development). Model pengembangan dalam penelitian dan pengembangan ini mengikuti de sain dari Borg \& Gall (1983:775) yang terdiri atas 10 langkah. Langkah-langkah itu adalah: (1) mengumpulkan informasi dan melakukan penelitian awal (research and information collecting; (2) perencanaan (planning); (3) pengembangan draf produk awal (developing preliminary form of product); (4) uji cobaawal (preliminary field testing); (5) revisi terhadap hasil uji coba (main product re vision); (6) uji coba lapangan (main field testing); (7) revisi produk hasil uji coba lapangan (operational product revision); (8) uji pelaksanaan lapangan (operational field testing); (9) revisi produk akhir (final product revision); dan (10) diseminasi dan implementasi (dissemination and implementation). Produk yang dikembangkan adalah perangkat pembelajaran. Pada bulan pertama dilakukan studi pendahuluan dan pengembangan produk yang berupa perangkat pembelajaran. Pada bulan kedua dilakukan uji coba produk LKPD di SD. Bulan ketiga dilakukan evaluasi revisi dan finalisasi perangkat pembelajaran di SD

Uji coba produk dalam penelitian pengembangan bertujuan untuk menyempurnakan produk dengan mempraktikkannya secara langsung di lapangan. Uji coba dilakukan melalui tahap: (1) produk awal (validasi ahli materi, karakter dan evaluasi); (2) uji coba awal (uji coba kelompok kecil dengan metode single one shot study); (3) uji coba lapangan (uji coba lapangan dengan metode one group pretest-postest); dan (4) uji lapangan (uji lapangan dengan metode Q uasi eksperiment). Subjek coba dalam penelitian adalah peserta didik kelas IV SDN Salamrejo. Subjek uji coba kelompok kecil di kelas IVA berjumlah 4 peserta didik. Subjek uji coba lapangan di kelas IVA berjumlah 10 peserta didik. Uji lapangan menggunakan kelas IVB sebagai kelas kontrol berjumlah 20 peserta didik dan IVC sebagai kelas eksperimen berjumlah 19 peserta didik.

Untuk pengumpulan data digunakan beberapainstrumen, yaitu observasi dengan pedoman penilaian produk untuk memperoleh data tentang validitas perangkat pembelajaran dari ahli materi dan ahli pembeIajaran. Lembar validasi digunakan untuk menentukan keefektifan perangkat pembelajaran yang dihasilkan. Di samping itu, digunakan juga rating scale yang bertujuan untuk mengamati karakter disiplin dan peduli yang muncul pada diri peserta didik dalam proses pembelajaran saat uji coba lapangan dan uji lapangan berdasarkan observasi secara langsung. Rating scale ini menggunakan skala likert dengan kriteria lima skala. Kerja observasi ini dilakukan pada pada saat uji coba lapangan, dan uji 
lapangan. Rating scale ini menggunakan skala likert dengan lima skala.

Instrumen wawancara juga digunakan untuk melengkapi data yang diperoleh dari observasi. Instrumen ini digunakan pada tahap penelitian dan pengumpulan informasi awal serta uji lapangan. Wawancara yang digunakan adalah wawancara tertutup untuk memperoleh informasi dan penjelasan dari subjek penelitian tentang penerapan Kurikulum 2013 serta permasalahan yang terkait dengan penerapan Kurikulum 2013. Pada tahap uji lapangan instrumen ini digunakan untuk memperoleh pendapat dari guru mengenai kesesuaian LKPD dengan harapan guru dan Kurikulum 2013. Instrumen angket digunakan untuk memperoleh respons guru untuk menilai keefektifan produk yang dikembangkan dan respons siswa untuk mendapatkan data mengenai pendapat siswa tentang proses pembelajaran yang dialami. Penentuan skor dibuat dalam skala lima.

Teknik analisis data yang digunakan adalah analisis data deskriptif, yakni analisis data deskriptif kuantitatif yang dilakukan untuk menganalisis data hasil observasi. Kualitas draf perangkat pembelajaran disusun dan dianalisis oleh para ahli materi, ahli karakter dan ahli evaluasi sebelum pelaksanaan uji coba awal, uji coba lapangan, dan uji lapangan. Berdasarkan ketiga hasil uji coba diperoleh sejumlah data kuantitatif. Data tersebut kemudian dianalisis untuk memperoleh produk penelitian akhir yang diharapkan, yaitu berupa perangkatpembelajaran berbasis scientific approach untuk membangun karakter kepedulian dan kedisiplinan.

Langkah-langkah analisis data kelayakan perangkat pembelajaran dilakukan dengan mengubah penilaian dalam bentuk kualitatif menjadi kuantitatif dengan ketentuan skor 5 untuk kriteria sangat baik, skor
4 untuk kriteria baik, skor 3 untuk kriteria cukup, skor 2 untuk kriteria kurang, dan skor 1 untuk kriteria sangat kurang. Hasil penilaian terhadap item-itemobservasi yang terkumpul dihitung skor rata-ratanya. Selanjutnya skor rata-rata dikonversi menjadi nilai kualitatif dengan kriteria penilaian yang akan dipaparkan pada Tabel 1 (Azwar, 2012:163).

\section{Tabel 1. Konversi Skor Nilai Skala 5}

\begin{tabular}{ccc}
\hline Nilai & Rentang Skor & Kategori \\
\hline A & $X>(M+1,50 s)$ & Sangat Baik \\
B & $(M+0,50 s)<X \leq$ & Baik \\
& $(M+1,50 s)$ & \\
C & $(M-0,50 s)<X \leq$ & Cukup \\
& $(M+0,50 s)$ & \\
D & $(M-1,50 s)<X \leq$ & Kurang \\
E & $(M-0,50 s)$ & Sangat Kurang \\
\hline
\end{tabular}

Keterangan:

$\mathrm{X}=$ skor rata-rata

$M=$ rata-rata ideal

$\mathrm{s}=$ simpangan baku

Kriteria kelayakan terendah penelitian ini adalah nilai minimal $B$ dengan kategori baik. Jadi, jika hasil penilaian reratanya menunjukkan hasil akhir B, maka produk dapat dianggap layak digunakan.

A nalisis angket respons guru dan peserta didik dilakukan dengan cara menghitung rata-rata skor yang diberikan oleh peserta didik. Rata-rata skor yang diberikan oleh peserta didik tersebut kemudian dikonversi menjadi skala empat. Adapun acuan penafsiran skor ke dalam skala empat adalah seperti pada Tabel 2 (Depdiknas, 2010:60).

\section{Tabel 2. Konversi Skor menjadi Nilai} Skala 4

\begin{tabular}{lcc}
\hline \multicolumn{1}{c}{ Rentang Skor } & Nilai & Kategori \\
\hline$x+1,5 . S D \leq x i \geq x+3,0 . S D$ & A & Sangat Baik \\
$x+0$. SD $\leq x i \geq x+1,5 . S D$ & B & Baik \\
$x-1,5$. SD $\leq x i \geq x+0$. SD & C & Kurang Baik \\
$x-3,0$. SD $\leq x i \geq x-1,5 . S D$ & D & Sangat Kurang Baik \\
\hline
\end{tabular}


Analisis peningkatan karakter disiplin dan peduli dilakukan untuk menentukan pengaruh perangkat pembelajaran dilihat dari hasil pre-test dan post-test melalui hasil observasi karakter siswa. Rating scale karakter kedisiplinan dan kepedulian yang diisi oleh observer menghasilkan rata-rata skor yang akan dianalils. Rata-rata skor yang dihasilkan akan dikonversikan menjadi skala empat. Acuan penafsiran skor ke dalam skala empat seperti pada Tabel 3 (diadaptasi dari Depdiknas, 2010:60).

Analisis perbedaan karakter disiplin dan peduli juga dilakukan. Data yang akan dianalisis dalam penelitian ini adalah karakter disiplin dan peduli. Analisis dilakukan untuk mengetahui perbedaan peningkatan karakter disiplin dan peduli pada kelaseksperimen dan kelas kontrol. Uji prasyarat yang harus dipenuhi sebelum uji t adalah uji normalitas dan uji homogenitas. Uji normalitas dilakukan untuk mengetahui apakah data dari masing-masing variabel berdistribusi normal atau tidak. Uji normalitas dilakukan terhadap standar karakter disiplin dan peduli. Uji normalitas dilakukan menggunakan uji kolmogrorovsmirnov. Uji homogenitas bertujuan untuk mengetahui apakah data pada kelompok eksperimen dan kelompok kontrol mempunyai varians yang sama atau tidak. Uji homogenitas varians dilakukan terhadap data karakter disiplin dan peduli. Uji homogenitas karakter disiplin dan peduli dilakukan menggunakan uji $\mathrm{F}$ dengan taraf signifikansi 5\%.

\section{HASIL DAN PEMBAHASAN H asil V alidasi Produk}

Produk yang dikembangkan dalam penelitian ini berupa perangkat pembelajaran berbasis scientific approach untuk membangun karakter kepedulian dan kedisiplinan. Produk yang berupa perangkatpem- belajaran ini telah divalidasi oleh beberapa ahli. Data hasil validasi perangkat pembelajaran berbasis scientific approach meliputi data hasil penilaian oleh ahli materi dan ahli pembelajaran. Data ini berupa skor penilaian dan masukan terhadap produk LKPD tematik-integratif berbasis karakter yang dikembangkan.

Tabel 3. Kategorisasi Karakter Peserta Didik

\begin{tabular}{ccc}
\hline $\begin{array}{c}\text { Rentang } \\
\text { Skor }\end{array}$ & Nilai & Kategori \\
\hline $\bar{x}+1,5 \mathrm{SBi} \leq \mathrm{X} \geq \bar{x}$ & A & $\begin{array}{c}\text { Sudah Membudaya } \\
+3,0 \mathrm{Sbi}\end{array}$ \\
$\bar{x}+0 . \mathrm{SBi} \leq \mathrm{X}<\bar{x}+$ & B & $\begin{array}{c}\text { Mulai Berkembang } \\
1,5 \mathrm{Sbi}\end{array}$ \\
$\bar{x}-1,5 \mathrm{SBi} \leq \mathrm{X}<\bar{x}$ & C & Mulai Terlihat (MT) \\
$+0 . \mathrm{Sbi}$ & & \\
$\bar{x}-3,0 \mathrm{SBi} \leq \mathrm{X}<\bar{x}-$ & D & Belum Terlihat (BT) \\
$1,5 \mathrm{Sbi}$ & & \\
\hline
\end{tabular}

Keterangan:

$\mathrm{x}=$ skor yang dicapai

$\bar{x}=$ rerata skor ideal $=(1 / 2)$ (skor tertinggi ideal + skor terendah ideal).

$S B i=(1 / 6)$ (skor tertinggi ideal - skor terendah ideal)

Tabel 4. Hasil Validasi Perangkat Pembelajaran

\begin{tabular}{lc}
\hline \multicolumn{1}{c}{ Aspek } & Kategori \\
\hline Silabus & Sangat Baik \\
RPP & Sangat baik \\
LKS & Sangat baik \\
Instrumen Penilaian & Sangat baik \\
\hline
\end{tabular}

Validasi yang dilakukan oleh ahli materi dan ahli pembelajaran memberi hasil penilaian terhadap perangkat pembelajaran yang dikategorikan sangat baik. Artinya, pengembangan perangkat pembelajaran untuk mengembangkan karakter disiplin dan peduli sudah baik. Berdasarkan penilaian di atas, dapat disimpulkan bahwa pengembangan perangkat pembelajaran 
dari ahli materi dan ahli pembelajaran memberi penilaian sangat baik sehingga layak untuk dilakukan uji coba lapangan di SD N Salamrejo

\section{Uji Coba A wal}

Uji coba awal dilakukan kepada siswa kelas IV SDN Salamrejo. Siswa yang digunakan sebagai subjek uji coba sebanyak 4 peserta. Tujuan dilaksanakannya uji coba ini adalah untuk mengumpulkan informasi berupa tingkat keefektifan perangkat pembelajaran yang dapat digunakan sebagai bahan untuk memperbaiki produk dalam analisis revisi berikutnya. Informasi yang terkumpul selama uji coba awal berupa hasil penilaian guru, hasil respons siswa, data pengamatan karakter siswa, penilaian karakter siswa, dan hasil penilaian tes akhir (posttest).

Keefektifan perangkat pembelajaran diketahui dengan pengisian lembar penilaian guru terhadap perangkat pembelajaran oleh guru kelas IV dan pengisian respons siswa terhadap proses pembelajaran yang berlangsung pada siswa kelas IV. Sajian hasil penilaian guru terhadap perangkat pembelajaran untuk masing-masing komponen perangkat pembelajaran dapat dilihat pada Gambar 1.

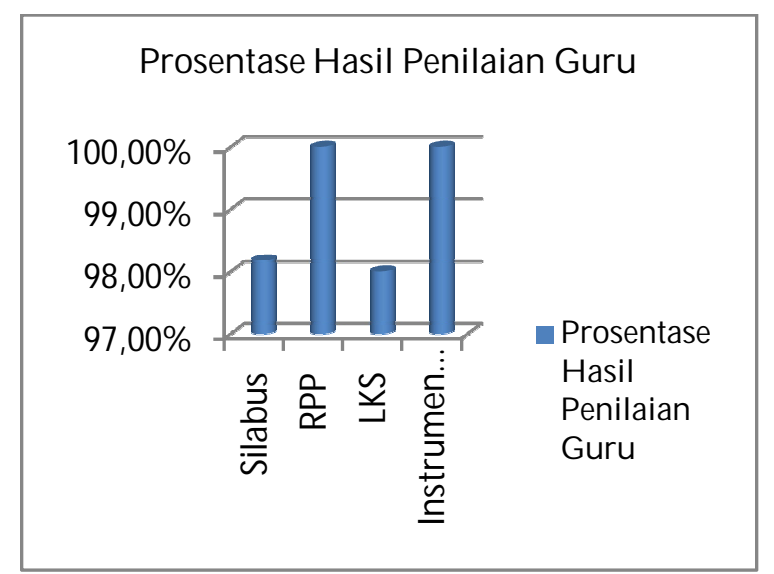

Gambar 1. Diagram Keefektifan

Perangkat Pembelajaran Penilaian Guru Uji Coba A wal
Berdasarkan hasil analisis, total skor aktual penilaian guru yang diperoleh pada uji coba awal ini berada pada interval berkategori sangat baik. Hal ini memberikan informasi bahwa perangkat pembelajaran efektif digunakan dalam pembelajaran.

Berdasarkan hasil analisis dari kedua komponen keefektifan perangkat pembelajaran terlihat bahwa perangkat pembelajaran yang dikembangkan berkategori sangat baik. Selain itu, jumlah siswa yang menilai perangkat pembelajaran berkategori sangat baik telah memenuhi syarat keefektifan yaitu lebih dari $80 \%$. Oleh karena itu, dapat disimpulkan bahwa perangkat pembelajaran yang diukur melalui komponen penilaian guru dan respon siswa pada uji coba awal memenuhi kategori keefektifan.

Pengukuran tingkat keefektifan perangkat pembelajaran juga dilakukan pada komponen observasi karakter siswa. Hasil prosentasepengamatan karakter siswayang telah dikonversi menjadi nilai skala lima untuk masing-masing karakter dapat dilihat Gambar 2 dan Gambar 3.

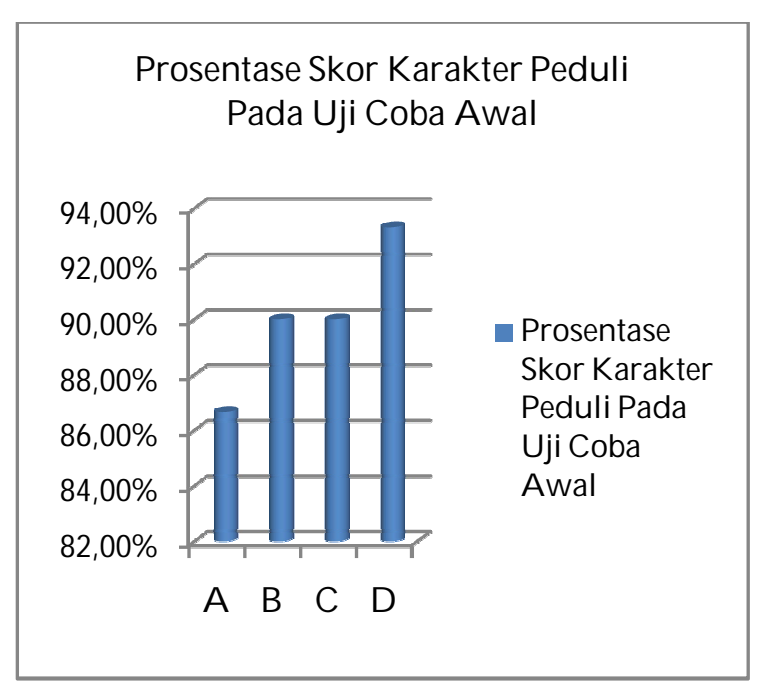

\footnotetext{
G ambar 2. D iagram Hasil Penilaian Karakter Peduli Siswa Uji Coba A wal
} 
ProsentasePenilaian Karakter Disiplin Uji Coba A wal

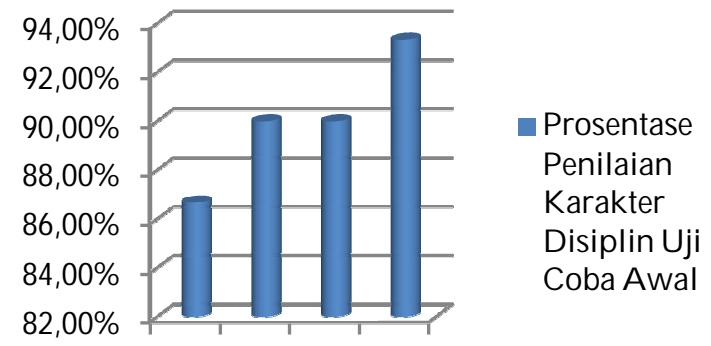

A $\quad$ B $\quad C \quad$ D

\section{Gambar 3. Diagram Hasil Penilaian} Karakter Disiplin Siswa Uji Coba A wal

Pada Gamba 2 dan 3 terlihat persentase penilaian karakter peduli dan disiplin setiap siswa di atas $80 \%$. Hal ini menunjukkan perangkat pembelajaran terbukti efektif dalam mengembangkan karakter peduli dan disiplin. Berdasarkan pengamatan, pengembangan karakter kepedulian dan kedisiplinan juga ditunjukkan dalam hal perubahan sikap anak. A nak yang semula suka membuang sampah sembarangan, mencoret-coret meja, tidak mencuci tangan sebelum makan menjadi berubah setelah pembelajaran. Pendekatan yang digunakan dalam mengembangkan karakter tersebut adalah pendekatan inkulkasi. Melalui pendekatan ini, anak diajak untuk membiasakan diri berperilaku disiplin dan peduli. Inkulkasi ini dilakukan terintegrasi dengan pembelajaran di kelas, misalnya dengan pembuatan poster untuk menjagalingkungan, melalui teks bacaan, melalui refleksi dalam setiap pembelajaran dan pembiasaan di sekolah.

Indikator hadir tepat waktu, tanggung jawab dan taat pada peraturan diterapkan melalui pendekatan modeling. Di sini guru sekaligus peneliti memberi contoh kepada siswa. Pada saat piket kelas, guru juga ikut terlibat di dalamnya, sehingga siswa akan enggan bila tidak mengerjakan piket kelas.
Dalam hal disiplin waktu siswa dan guru membuat perjanjian untuk mengurangi bintang di kelas jika hadir terlambat ataupun melakukan satu pelanggaran tata tertib. Dengan demikian, perubahan karakter siswa cukup nampak dalam uji coba awal ini.

\section{H asil U ji Coba Lapangan}

Uji coba lapangan dilakukan kepada siswa kelas IV SDN Salamrejo. Siswa yang digunakan sebagai subjek uji coba sebanyak 10 peserta yang tidak ikut uji coba awal. Tujuan dilaksanakannya uji coba ini adalah untuk mengumpulkan informasi berupa tingkat keefektifan perangkat pembelajaran yang dapat digunakan sebagai bahan untuk memperbaiki produk dalam analisis revisi berikutnya. Informasi yang terkumpul selama uji coba lapangan berupa hasil penilaian guru, hasil respons siswa, penilaian karakter siswa, dan hasil penilaian tes akhir (posttest).

Keefektifan perangkat pembelajaran diketahui dengan pengisian lembar penilaian guru terhadap perangkat pembelajaran oleh guru kelas IV dan pengisian respons siswa terhadap proses pembelajaran yang berlangsung oleh siswa kelas IV. Sajian persentase penilaian guru terhadap perangkat pembelajaran untuk masing-masing komponen perangkat pembelajaran dapat dilihat pada Gambar 4.

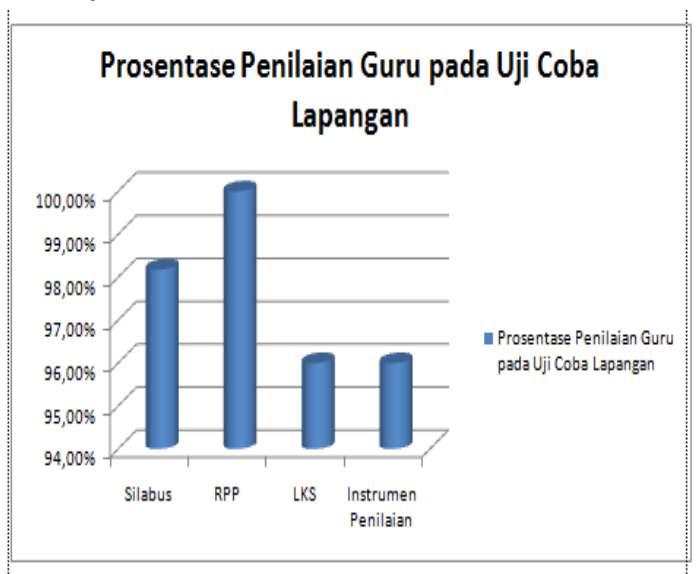

G ambar 4. D iagram Persentase Penilaian G uru Uji Coba Lapangan 
Berdasarkan Gambar 4, dapat dike tahui persentase penilaian guru terhadap perangkat pembelajaran di atas $80 \%$. $\mathrm{Hal}$ ini memberikan informasi bahwa perangkat pembelajaran dinilai efektif digunakan dalam pembelajaran. Kriteria keefektifan perangkat pembelajaran juga dilihat dari tingkat respon siswa terhadap perangkat pembelajaran melalui proses pembelajaran. Perentase respons siswa pada uji coba lapangan dapat dilihat pada Gambar 5.

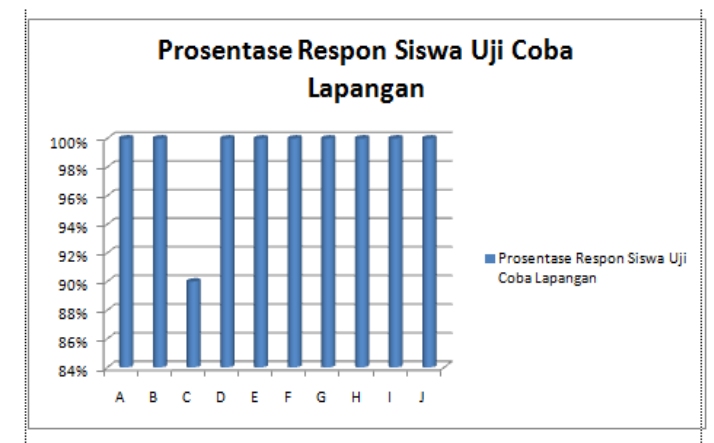

\section{G ambar 5. D iagram Persentase Respons}

\section{Siswa Uji Coba Lapangan}

Berdasarkan Gambar 5, persentaseresponssiswaterhadap perangkat pembelajaran yang dikembangkan rata-rata $100 \%$. Se bagian besar siswa menyatakan bahwa perangkat pembelajaran yang dikembangkan berkategori sangat baik. Sementara itu, hasil analisis rerata total skor aktual respon siswa yang dikonversikan menjadi data skala lima juga menyimpulkan bahwa perangkat pembelajaran berada pada kategori sangat baik yang mengindikasikan bahwa perangkat pembelajaran dinilai efektif oleh siswa untuk meningkatkan kepedulian dan kedisiplinan.

Berdasarkan hasil analisis dari kedua komponen keefektifan perangkat pembelajaran menunjukkan bahwa perangkat pembelajaran yang dikembangkan telah memenuhi syarat keefektifan, yaitu lebih dari 80\%. Oleh karena itu, dapat disimpulkan bahwa perangkat pembelajaran yang diukur melalui komponen penilaian guru dan respons siswa pada uji coba lapangan memenuhi kategori efektif.

Kriteria keefektifan perangkat pembelajaran juga diukur melalui penilaian terhadap tes hasil belajar dan penilaian karakter siswa. A pabila disajikan dalam bentuk diagramtes hasil belajar siswayang memenuhi kriteria tuntas dapat dilihat pada Gambar 6.

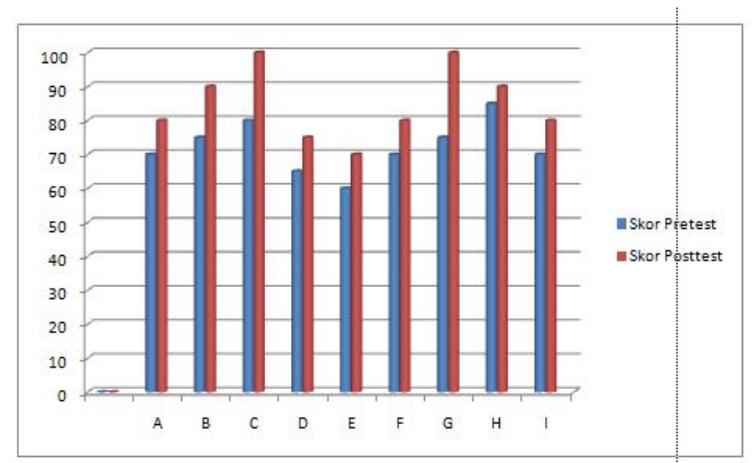

\section{Gambar 6. Diagram Keefektifan Tes Hasil Belajar Siswa Uji Coba Lapangan}

Berdasarkan Gambar 6, hasil posttest semua siswa tuntas mengikuti penilaian tes hasil belajar, yaitu di atas KKM SDN Salamrejo sebesar 70. Hal ini mengindikasikan bahwa perangkat pembelajaran yang dikembangkan terbukti efektif karena siswa berhasil tuntas mengerjakan dengan benar tes yang diberikan.

Pengukuran tingkat keefektifan perangkat pembelajaran juga dilakukan pada komponen pengamatan karakter siswa. Hasil persentase penilaian karakter siswa dapat dilihat Gambar 7 dan Gambar 8.

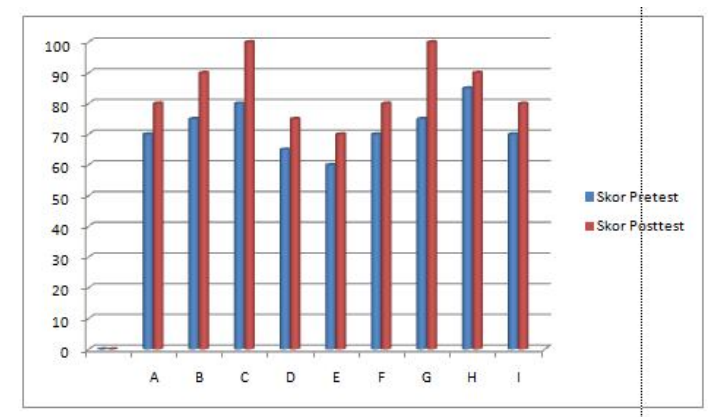

G ambar 7. D iagram Persentase Karakter Peduli Siswa pada Uji Coba Lapangan 


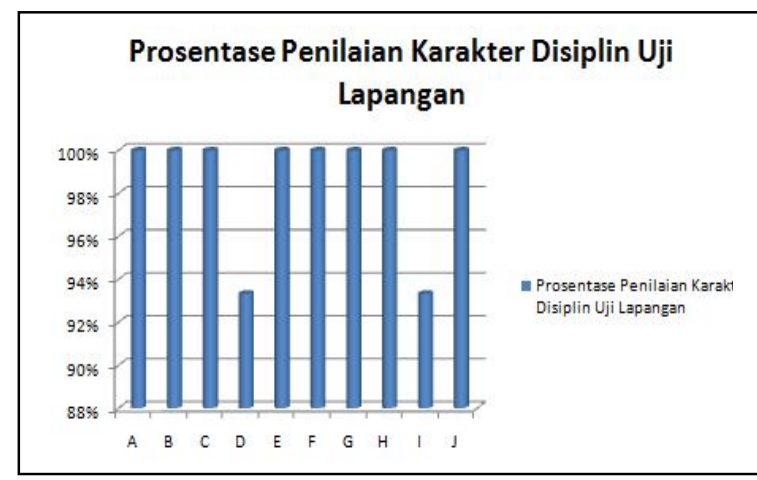

G ambar 8. D iagram Persentase Karakter Disiplin Siswa pada Uji Coba Lapangan

Hasil analisis yang telah dilakukan menunjukkan bahwa hasil penilaian terhadap hasil belajar (posttest), observasi karakter, dan penilaian karakter siswa rata-rata berkategori sangat baik. Jumlah siswa yang memenuhi kategori sangat baik pada masing-masing komponen juga lebih dari 80\%. Dengan demikian, dapat disimpulkan bahwa perangkat pembelajaran yang dikembangkan dan diujikan pada kelompok kecil efektif digunakan untuk meningkatkan karakter siswa.

\section{U ji Coba Lapangan O perasional}

Uji coba lapangan operasional untuk mengetahui ada tidaknya perbedaan terhadap pengembangan karakter dan hasil belajar Subtema Keindahan Alam Negeriku pada KK dan KE digunakan uji-t. Sebelum melakukan uji t diperlukan prasyarat analisis, yaitu berupa uji normalitas dan uji homogenitas.

\section{U ji N ormalitas dan U ji H omogenitas}

Uji normalitas dilakukan dengan menggunakan uji Kolmogorov-Smirnov pada taraf signifikansi 0,05. Hasil uji normalitas data karakter disiplin dan peduli ditunjukkan pada Tabel 5. Berdasarkan Tabel 5, terlihat bahwa harga signifikansi hasil belajar sub tema Keindahan Alam Negeriku, karakter peduli dan disiplin lebih besar dari 0,05 (Sign $(p)>0,05$ ). Dengan demikian, Ho diterima atau data tersebut berdistribusi normal. Hasil uji homogenitas dapat dilihat pada Tabel 6.

Tabel 5. Rangkuman Uji Normalitas

\begin{tabular}{lcccl}
\hline Data & \multicolumn{2}{c}{ Sig. $(p)$} & Kondisi & Ket \\
\cline { 2 - 3 } & KK & KE & & \\
\hline Hasil & 0,999 & 0,805 & $\mathrm{P}>0,05$ & Normal \\
Belajar & & & & \\
Peduli & 0,566 & 0,641 & $\mathrm{P}>0,05$ & Normal \\
Disiplin & 0,744 & 0,435 & $\mathrm{P}>0,05$ & Normal \\
\hline
\end{tabular}

Tabel 6. Rangkuman Uji Homogenitas

\begin{tabular}{lccc}
\hline \multicolumn{1}{c}{ Data } & Fhitung & F Tabel & Ket \\
\hline $\begin{array}{l}\text { Hasil } \\
\text { belajar }\end{array}$ & 1,151 & 4,105 & Homogen \\
$\begin{array}{l}\text { Peduli } \\
\text { Disiplin }\end{array}$ & $\mathbf{1 , 3 6 3}$ & 4,105 & Homogen \\
\hline
\end{tabular}

Tabel 6 menunjukkan bahwa kedua sampel dalam populasi dalam keadaan homogen atau sama. Hal ini ditunjukkan dengan Fhitung < Ftabel. Dengan demikian, Ho diterima atau data tersebut bersifat homogen. Data yang berdistribusi normal dan bersifat homogen kemudian dilakukan uji-t (independent sample t-test) dengan program SPSS.

\section{Analisis Perbedaan Ketercapaian Pengem- bangan Karakter Peduli}

Untuk melakukan uji-t sebelumnya diperlukan hipotesis penelitian sebagai be rikut. Pertama, Ho: tidak ada perbedaan yang signifikan terhadap ketercapaian pengembangan karakter peduli antara siswa yang mengikuti pembelajaran tanpa perangkat pembelajaran dan menggunakan perangkat pembelajaran hasil pengembangan. Kedua, $\mathrm{Ha}$ : ada perbedaan yang signifikan terhadap ketercapaian pengembangan karakter peduli antara siswa yang mengikuti pembelajaran tanpa perangkat 
pembelajaran dan menggunakan perangkat pembelajaran hasil pengembangan.

Pengujian hipotesis dilakukan pada data skor yang diperoleh dari rerata skor hasil observasi pengamatan di kelas. Secara singkat, hasil perhitungan independent sample t-test untuk kedua kelompok ditinjau dari ketercapaian pengembangan karakter peduli dapat diringkas dalam Tabel 7.

Tabel 7. Uji Beda Ketercapaian Karakter Peduli KK dan KE

\begin{tabular}{lcc}
\hline & KE & KK \\
\hline Mean & 26,60 & 23,47 \\
$\mathrm{~N}$ & 20 & 19 \\
t hitung & \multicolumn{2}{c}{4,854} \\
T tabel & \multicolumn{2}{c}{1,684} \\
A nalisis & t hitung $>$ t tabel \\
Keterangan & \multicolumn{2}{c}{ Signifikan } \\
\hline
\end{tabular}

Perbedaan dikatakan signifikan jika t hitung > t tabel. Jika t hitung $>$ t tabel, maka Ho ditolak dan Ha diterima. Berdasarkan kesimpulan tersebut ada perbedaan yang signifikan terhadap karakter peduli antara siswa yang mengikuti pembelajaran tanpa perangkat pembelajaran dan yang menggunakan perangkat pembelajaran hasil pengembangan.

\section{Analisis Perbedaan Ketercapaian Pena- naman Karakter D isiplin}

Untuk melakukan uji-tsebelumnyadiperlukan hipotesis penelitian sebagai berikut. Pertama, Ho: tidak ada perbedaan yang signifikan terhadap ketercapaian pengembangan karakter disiplin antara siswa yang mengikuti pembelajaran tanpa perangkat pembelajaran dan menggunakan perangkat pembelajaran hasil pengembangan. $\mathrm{Ke}$ dua, Ha: ada perbedaan yang signifikan terhadap ketercapaian pengembangan karakter disiplin antara siswa yang mengikuti pembelajaran tanpa perangkat pembelajar- an dan menggunkan perangkat pembelajaran hasil pengembangan.

Pengujian hipotesis dilakukan pada data skor yang diperoleh dari rerata skor hasil observasi pengamatan di kelas. Secara singkat hasil perhitungan independent sample t-test untuk kedua kelompok ditinjau dari ketercapaian pengembangan karakter disiplin dapat diringkas dalam Tabel 8.

Tabel 8. Uji Beda Ketercapaian Karakter Disiplin KK dan KE

\begin{tabular}{lcc}
\hline & KE & KK \\
\hline Mean & 13,05 & 12,10 \\
$\mathrm{~N}$ & 20 & 19 \\
t hitung & \multicolumn{2}{c}{1,926} \\
T tabel & \multicolumn{2}{c}{1,684} \\
Analisis & t hitung $>$ t tabel \\
Keterangan & \multicolumn{2}{c}{ Signifikan } \\
\hline
\end{tabular}

Perbedaan dikatakan signifikan jika t hitung $>$ t tabel. Jika t hitung $>$ t tabel, maka Ho ditolak dan $\mathrm{Ha}$ diterima. Berdasarkan kesimpulan tersebut, ada perbedaan yang signifikan terhadap karakter disiplin antara siswa yang mengikuti pembelajaran tanpa perangkat pembelajaran dan menggunakan perangkat pembelajaran hasil pengembangan.

\section{Pembahasan Produk Akhir}

Produk akhir dari pengembangan ini adalah perangkat pembelajaran berbasis scientific approach untuk membangun karakter disiplin dan peduli untuk peserta didik kelas IV SD Negeri Salamrejo. Perangkat pembelajaran ini disusun dengan subtema "Keindahan Alam N egeriku". Perangkat pembelajaran untuk membangun karakter disiplin dan peduli memuat berbagai pengalaman belajar. Schunk (2012: 333) mengatakan bahwa anak-anak mulai menunjukan beberapa pemikiran abstrak meskipun biasanya didefinisikan dengan karakter-karakter atau tindakan-tindakan. 
Kegiatan di dalam perangkat pembelajaran memacu pengalaman langsung, eksperimen, wawancara, demostrasi, diskusi kelompok, dan mengerjakan soal di dalam LKS. Oleh karena itu, perangkat pembelajaran dapat membuat peserta didik lebih tertarik untuk belajar karena setiap pembelajaran pada perangkat pembelajaran bertitik tolak pada alam nyata yang sesuai de ngan dunia peserta didik, khususnya dalam pengembangan karakter kepedulian dan kedisiplinan.

$\mathrm{Hal}$ ini diperkuat oleh pendapat Yuldirim \& A yas (2011:45) yang menegaskan:

“Thus worksheets are known to help students gain scientific process skills such as setting up experimental mechanism, recording data, interpreting the data, and so on so that they can conceptualize the concepts in ther minds. There are several studies showing that worksheets increase students".

Pendapat di atas mengandung maksud bahwalembar kerja dikenal untuk membantu peserta didik memperoleh keterampilan proses ilmiah, seperti menyiapkan mekanisme eksperimental, merekam data, menafsirkan data, dan sebagainya sehingga mereka memiliki konsep dalam pikiran. Melalui kegiatan-kegiatan tersebut, dapat memacu peserta didik untuk aktif secara mandiri dan kelompok di sekolah, di rumah, dan di lingkungan masyarakat.

Perangkat pembelajaran tema "Keindahan Alam Negeriku" ini bertujuan untuk mengembangkan karakter disiplin dan peduli dimaksudkan agar peserta didik memiliki sikap yang disiplin dan kepedulian yang tinggi terhadap sesama manusia dan makhluk hidup di lingkungan sekitarnya. Selain itu, juga bertujuan untuk membimbing peserta didik di dalam kegiatan pembelajaran dan mempermudah penyerapan ilmu.
Perangkat pembelajaran efektif untuk menanamkan karakter disiplin dan peduli. perangkat pembelajaran berbasis karakter memiliki kelebihan pada proses scientific approach yang mendorong peserta didik dalam penanaman karakter. Berdasarkan hasil observasi karakter disiplin dan peduli pada kelas eksperimen dan kelas kontrol menunjukkan peningkatan pada kelas eksperimen lebih besar daripada kelas kontrol. $\mathrm{Hal}$ ini menunjukkan bahwa terdapat perbedaan yang signifikan rerata peningkatan karakter disiplin dan peduli peserta didik yang mengikuti pembelajaran menggunakan perangkat pembelajaran yang telah dikembangkan dengan peserta didik yang mengikuti pembelajaran tanpa menggunakan perangkat pembelajaran yang telah dikembangkan. Hal ini menunjukkan bahwa penggunaan perangkat pembelajaran ini memberikan pengaruh positif terdahap peningkatan karakter peserta didik. Hal ini senada dengan pendapat Stedje (2010:4), "Character education occurs each minute in the classroom". Artinya, bahwa pendidikan karakter terjadi setiap menit di dalam kelas. Karakter peserta didik akan semakin terbentuk dengan semakin seringnya peserta didik melakukan aktivitas pada berbasis karakter karena karakter merupakan sifat desposisi seseorang yang relatif stabil.

Perangkat pembelajaran yang dikembangkan memuat unsur pedagogik yang terdiri atas penemuan konsep, petunjuk belajar yang tertera di dalam bagan dengan kalimat yang jelas dan mudah dipahami, adanya kompetensi yang akan dicapai dan indikator penjabarannya, informasi pendukung yang bervariasi, singkat, dan menarik, petunjuk kerja atau lembar kerja yang sesuai dengan kegiatan yang akan dilakukan misalnya terdapat lembar wawancara, lembar kegiatan individu, lembar kegiatan kelompok, lembar berimajinasi, lembar 
berkreasi dengan alam, dan lembar membuat poster dan mempublikasikannya. Kegiatan dalam perangkat pembelajaran ini mengarahkan dan memicu pada kegiatan yang menarik, demonstrasi, wawancara, berkreasi, berimajinasi, dokumentasi, bertukar pikiran, dan lainnya. Perangkat pembelajaran ini memiliki bagan penguatan karakter pada setiap pertemuan yang berisi simpulan kegiatan pembelajaran dan pe nguatan karakter disiplin dan peduli.

Di dalam perangkat pembelajaran ini terdapat lima kegiatan dengan pendekatan scientific yang sesuai dengan pengembangan karakter. Temuan dalam uji lapangan mengenai karakter disiplin dan peduli sebagai berikut. Pertama, karakter disipin terlihat dari meningkatnya kedispinan dalam hal waktu, tidak terlambat ketika be rangkatsekolah, tanggung jawab dalam melaksanakan tugas, dan taat pada tata tertib. Kedua, karakter peduli terlihat dari me ningkatnya rasa kepedulian peserta didik terhadap lingkungan. Melalui poster yang dibuat, siswa mengajak siswa lain untuk menjaga lingkungan. Melalui pembiasaan, siswamelaksanakan tugaspiketkelas, membuang sampah pada tempatnya. Siswa juga bertanggung jawab untuk memelihara tanaman di depan kelas dan di halaman sekolah.

Perangkat pembelajaran ini secara khusus membangun duakarakter yang spesifik, yaitu karakter disiplin dan peduli. $\mathrm{Pe}$ serta didik diajak untuk memahami, melakukan, dan membiasakan perilaku disiplin dan peduli di dalam kegiatan pembelajaran di sekolah, di rumah, dan di lingkungan masyarakat. Perangkat pembelajaran ini juga membangun kepedulian peserta didik terhadap makhluk hidup di lingkungannya dengan tidak merusak lingkungan, menjaga, merawat dan melestarikannya.

\section{PENUTUP}

Berdasarkan hasil Berdasarkan hasil penelitian dan pembahasan, dapat diambil kesimpulan sebagai berikut.

- Perangkat pembelajaran berbasis scientific approach subtema Keindahan Alam Negeriku yang dikembangkan untuk membangun karakter kepedulian dan kedisiplinan dinilai layak untuk digunakan menurut ahli materi dengan nilai sangat baik pada produk perangkat pembelajaran.

- Perangkat pembelajaran berbasis scientific approach subtema Keindahan Alam Negeriku yang dikembangkan untuk membangun karakter kepedulian dan kedisiplinan dinilai layak digunakan menurut ahli pembelajaran dengan nilai sangat baik pada produk perangkat pembelajaran.

- Perangkat pembelajaran berbasis scientific approach subtema Keindahan Alam Negeriku terbukti efektif untuk membangun karakter kepedulian siswa kelas IV. Hal ini didasarkan pada uji coba lapangan operasional dengan hasil uji t sebesar 4, 854 pada karakter peduli lebih besar dari $t$ tabel sebesar 1, 684 sehingga dapat disimpulkan ada perbedaan yang signifikan terhadap pengembangan karakter peduli antara siswa yang mengikuti pembelajaran tanpa perangkat pembelajaran dan menggunakan perangkat pembelajaran hasil pengembangan.

- Perangkat pembelajaran berbasis scientific approach sub tema Keindahan Alam Negeriku terbukti efektif untuk membangun karakter kedisiplinan siswa kelas IV. Hal ini didasarkan pada uji cobalapangan operasional yang menggunakan uji t pada kelas control dan kelas eksperimen dengan hasil uji t sebesar 1,926 pada karakter disiplin lebih besar dari t tabel sebesar 1 , 684 sehingga dapat disimpulkan ada perbedaan yang signifikan terhadap pengembangan karakter disiplin antara siswa 
yang mengikuti pembelajaran tanpa perangkat pembelajaran dan menggunakan perangkat pembelajaran hasil pengembangan.

\section{UCAPAN TERIMA KASIH}

Puji syukur diucapkan ke hadirat Allah Swt. atas terselesaikannya artikel ini. Dalam kesempatan ini penulis ingin mengucapkan terima kasih kepada semua pihak yang telah membantu dalam penyelesaian penelitian hingga penulisan artikel ini, terutama kepada Kaprodi Dikdas Program Pascasarjana Universitas Negeri Yogyakarta. Penulis juga mengucapkan terima kasih kepada Ketua dan Sekretaris Dewan Re daksi Jurnal Pendidikan Karakter yang banyak membantu penulis demi terselesaikan-nya artikel ini hingga dimuat dalam edisi ini.

\section{DAFTAR PUSTAKA}

Azwar, S. 2012. R eabilitas dan V aliditas. Yogyakarta: Pustaka Pelajar

Bohlin, K.E. 2005. Teaching Character Education through Literature A wakening the $M$ oral Imagination in Secondary Classrooms. N ew York: Routledge Falmer.

Borg, W.R., \& Gall, M.D. 1983. Educational Reseach an Introduction. New York: Longman.

Borich, G.D. 2007. Effective Teaching M ethods R esearch-Based PracticeSixth Edition. New Jersey: Pearson Merrill Prentice Hall.

Depdiknas. 2010. Juknis Pengembangan Bahan A jar SM A . Jakarta: DirektoratPembinaan Sekolah Dasar.
Dwiningrum, Siti Irene, dkk. 2013. IImu Sosial dan Budaya Dasar: Pendekatan Problem Solving dan Analisis Kasus. Yogyakarta: UNY Press

Lickona, T. 1991. Educating for C haracter: $\mathrm{H}$ ow O ur Schools Can Teach R espect and Responsibility. N ew York: Bantam Books.

Peraturan Menteri Pendidikan dan Kebudayaan RI Nomor 67Tahun 2013 Tentang Kerangka Dasar dan Struktur Kurikulum Sekolah Dasar/ Madrasah Ibtidaiyah.

Schunk, D.L. 2012. Teori-teori Pembelajaran (Terjemahan Eva Hamdiah, Ahmad Fajar). Yogyakarta: Pustaka Pelajar.

Stedje, L.B. 2010. N uts and Bolts of Character Education. www.characterfirst.com/ assets/ files/ character EducationsReport.pdf. Diunduh pada tanggal 29 Desember 2014

Tessier, J.T. 2003. "Applying Plant Identification Skills to Actively Learn the Scientific Method". The A merican Biology Teacher, Vol. 65, No. 1, hlm. 2529.

Undang-Undang Nomor 20 Tahun 2003 tentang Sistem Pendidikan N asional.

Usman, S. 2011. Pembelajaran IPA di Sekolah D asar. Jakarta: Indeks.

Yuldirim, N.\&Ayas, A. 2011. "The Effect of the Worksheet on Student Achievement in Chemical Equilibrium. Journal of Turkish Science Education Vol. 8, No. 3, September 2011. hlm. 44-51. 